\title{
Institutions in International Relations: Understanding the Effects of the GATT and the WTO on World Trade
}

\author{
Judith L. Goldstein, Douglas Rivers, and \\ Michael Tomz
}

\begin{abstract}
The General Agreement on Tariffs and Trade (GATT) and the World Trade Organization (WTO) have been touted as premier examples of international institutions, but few studies have offered empirical proof. This article comprehensively evaluates the effects of the GATT/WTO and other trade agreements since World War II. Our analysis is organized around two factors: institutional standing and institutional embeddedness. We show that many countries had rights and obligations, or institutional standing, in the GATT/WTO even though they were not formal members of the agreement. We also expand the analysis to include a range of other commercial agreements that were embedded with the GATT/WTO. Using data on dyadic trade since 1946, we demonstrate that the GATT/WTO substantially increased trade for countries with institutional standing, and that other embedded agreements had similarly positive effects. Moreover, our evidence suggests that international trade agreements have complemented, rather than undercut, each other.
\end{abstract}

When and how do international institutions promote cooperation? Few questions are as fundamental to international relations or as salient for world leaders. Due to the contributions of Keohane and others, we now have sophisticated theories about the emergence and effects of international institutions, but empirical research has not proceeded apace. ${ }^{1}$ As Frieden and Martin point out, "theoretical work on inter-

An earlier version of this article was presented at the $99^{\text {th }}$ Annual Meeting of the American Political Science Association, Philadelphia, August 28-31, 2003. We thank Tim Büthe, Joanne Gowa, Miles Kahler, Andrew Rose, Arthur Stein, Richard Steinberg, and seminar participants at Stanford University, the University of Chicago (PIPES), the University of California, Los Angeles, the University of California, San Diego, and the University of Virginia, for many helpful comments. We especially thank Claire Adida, Ashley Conner, Moonhawk Kim, Erin Krampetz, James Morrison, Mike Nardis, Natan Sachs, Rachel Rubinfeld, and Jessica Weeks for excellent research assistance. We are grateful for financial support from the National Science Foundation (CAREER grant SES-0548285 to Tomz), the Stanford Center for International Development, and the Vice Provost for Undergraduate Education at Stanford.

1. Keohane 1984.

International Organization 61, Winter 2007, pp. 37-67

(C) 2007 by The IO Foundation.

DOI: $10.1017 / \mathrm{S} 0020818307070014$ 
national institutions has far outstripped the quantity and quality of empirical work." ${ }^{2}$ At the moment, we cannot be sure that prominent institutions are performing according to theory, nor can we say which institutions are living up to their mandates.

The gap between theory and evidence appears starkly in analyses of the General Agreement on Tariffs and Trade (GATT) and its successor, the World Trade Organization (WTO). ${ }^{3}$ The GATT/WTO is one of the most cited examples of a successful international institution. Membership in the GATT/WTO has expanded dramatically since its founding, and international trade has grown in tandem. Many observers assume these trends are linked and praise the institution for transforming world commerce, ${ }^{4}$ but few have attempted to quantify the GATT/WTO's effect on the level and direction of trade.

Furthermore, contrary to expectations, the leading statistical analysis to date finds no evidence that the GATT/WTO increased trade among members, after controlling for national income, geography, and other factors that affect the flow of goods between nations. ${ }^{5}$ This null result not only challenges our understanding of the most heralded commercial agreement in history, but also casts doubt on the institutionalist literature that regards the GATT/WTO as its beau ideal. If the GATT/ WTO is inconsequential, what should one expect from thousands of other, ostensibly lesser, international agreements?

The following analysis seeks to fill the void between theoretical insight and empirical evidence by comprehensively evaluating the effects of trade agreements on trade flows in the years since World War II. We ask not only whether the GATT/ WTO has increased trade, but also how other agreements have altered the trade of nations. We then test our expectations by examining dyadic trade flows between 1946 and 2004.

Our analysis is organized around two factors: institutional standing and institutional embeddedness. A state, territory, or nongovernmental actor has standing to the extent that it possesses rights and obligations established by the institution. Much research on institutions has focused on formal members, by contrasting those who signed agreements with those who did not. We argue that standing, not formal membership, is the more useful concept for understanding incentives and behavior. Institutions such as the GATT/WTO create rights and obligations for nonmembers and therefore can have surprisingly broad effects. At the same time, institutions often contain opt-out clauses. It follows that, even within the core group of formal members, rights and obligations may be weaker for some parties than for others. The concept of standing, which can be wider or narrower than formal membership, helps us understand the true reach of international institutions.

2. Frieden and Martin 2002, 146.

3. The GATT went into effect in 1948 and was superseded by the World Trade Organization in 1995.

4. For example, see Bagwell and Staiger 2002b; Bhagwati 1991; Irwin 2002; Jackson 1997; Kahler 1995; and Ruggie 1993.

5. Rose 2004. 
We also introduce the concept of embeddedness and use it to assess the effect of different, but what many analysts see as functionally equivalent, institutions. Countries sign onto numerous trade agreements, which should be analyzed collectively to understand the full reach of the contemporary trading system. The GATT/ WTO, for example, has always coexisted with a myriad of overlapping commercial pacts. Some clearly reinforce the GATT/WTO, whereas others could make the institution superfluous. We examine four types of arrangements: the GATT/WTO; preferential trade agreements (PTAs) that grant a limited group of nations privileged access to each others' markets; nonreciprocal agreements such as the Generalized System of Preferences (GSP), which give preferential access into the market of one but not both trading partners; and colonial networks of trade.

Based on statistical analysis of standard and new data, we find that the GATT/ WTO boosted trade among signatories, and it exerted a similarly large effect on colonies and newly independent states that had not acceded but nonetheless possessed the rights and obligations of members. Moreover, other types of trade agreements apparently complemented, rather than undermined, the effectiveness of the GATT/WTO. We conclude that the institution transformed postwar trade, though not in the way previous scholars had thought.

The next two sections of the article apply the concepts of standing and embeddedness to commercial relations and use them to specify when the GATT/WTO should promote trade. We then describe our statistical model and data and present the empirical findings. We conclude by suggesting how attention to standing and embeddedness could advance our understanding of other international agreements.

\section{Standing: Rights and Obligations in International Organizations}

How should one study the effects of an international institution? The most obvious approach would be to compare relations between members to relations between nonmembers, but this approach would miss potentially important dimensions of cooperation. Agreements can impose externalities on relations between members and nonmembers, or even on relations between pairs of nonmembers. We develop this argument by invoking the concept of institutional standing, which captures the degree to which a country, territory, or nongovernmental actor has rights and obligations arising from the institution.

Standing differs from formal membership in two ways. First, some institutions give rights and obligations not only to formal members, but also to territories and groups that never signed the agreement. These nonmember participants have standing, and consequently the institution should influence their behavior. Second, even formal members do not necessarily accept all parts of an agreement as binding on themselves. Some employ opt-out clauses or express reservations that affect the distribution of rights and obligations. Given that nonmembers' incentives could be influenced by an agreement they never signed, and that constraints on signatories 
can vary, it is important to consider who has standing, not simply the list of formal members.

We test the implications of this insight through a detailed analysis of participation in the GATT/WTO since its inception. The institution was established "to remove or diminish barriers which impede the flow of international trade and to encourage by all available means the expansion of commerce." ${ }^{\prime 6}$ In pursuit of these objectives, the organization defined rules to govern trade policy and sponsored eight rounds of trade negotiations, which led to reciprocal reductions in tariffs and nontariff barriers. Participation in the organization both prohibited nations from deviating from regime rules and provided a set of potential benefits; most notably, that trading partner policies would be predictable and consistent with the general tenets of the organization.

Much has been written about how and why international agreements such as the GATT/WTO can foster trade. One line of argument suggests that GATT/WTO principles of reciprocity and nondiscrimination alleviate a prisoners' dilemma that occurs when each country sets its trade policy unilaterally according to a termsof-trade logic. ${ }^{7}$ Another focuses on time-inconsistency problems: the GATT/WTO reduces the likelihood that leaders will reinstate protectionism in response to domestic political pressure. ${ }^{8}$ A third line stresses how rules of the regime make it difficult to "back-slide" on an agreement, either because reciprocity makes it difficult to respond to domestic rent-seeking groups without hurting an exporting constituency or because of the existence of a dispute settlement mechanism. ${ }^{9}$ Each of these arguments suggests how standing in the GATT/WTO might increase trade.

The remainder of this section discusses the implications of standing with specific references to the history of the GATT. The category of formal membership understates the reach of the agreement in some cases and overstates it in others. The overall import of this omission, however, is to significantly underestimate the extent to which the GATT has promoted trade.

\section{Underestimating the Reach of the GATT/WTO}

To estimate the impact of an agreement on trade flows, one must identify the countries and territories that were bound by the agreement. As with other international agreements, the GATT/WTO created rights and obligations for its formal members, known as the Contracting Parties. In October 1947, twenty-three nations signed the General Agreement, pledging to implement the tariff reductions they had negotiated and to extend "most-favored nation" (MFN) treatment to all participants. The founders, as formal members, were required to pay dues and notify the orga-

6. GATT 1961, 1. See also Irwin 1995.

7. Bagwell and Staiger 1999 and 2002a.

8. See, for example, Staiger and Tabellini 1987, 1999; and Maggi and Rodríguez-Clare 1998.

9. See, for example, Gilligan 1997; Bailey, Goldstein, and Weingast 1997; and Barton, Goldstein, Josling, and Steinberg 2006. 
nization of changes in trade policy. They could participate in multilateral trade negotiations and annual meetings, and they had voting rights. When other countries formally acceded to the organization, they acquired the same duties and privileges as the founders.

Along with these formal members, a large group of other countries simultaneously came into the GATT/WTO. Many of the founding members, including the United States, retained colonies and overseas territories. Article XXVI:5(a) of the General Agreement specified that when sponsored by their metropole, colonies could receive and give the benefits of membership. With much of the world under colonial rule in the late 1940s, this clause greatly expanded the scope of the agreement beyond the original signatories. ${ }^{10}$ Although not all countries extended benefits to their colonial possessions, most did, making these colonial participants the largest group of partakers of the early GATT/WTO.

Colonies of formal members were not the only nonmember participants. Many newly independent nations had rights and obligations in the GATT/WTO for years before becoming formal members. Having accepted the agreement for their overseas territories, the Contracting Parties did not want to cut off these territories when they gained independence. The General Agreement stipulated two avenues by which decolonized nations could accede to the organization. Most simply, they could invoke Article XXVI:5(c), and thereby become a contracting party "on the terms and conditions previously accepted by the metropolitan government on behalf of the territory in question." ${ }^{11}$ Alternatively, ex-territories could negotiate new terms and attempt to enter via Article XXXIII. If neither option seemed attractive, the newly independent state could terminate its participation in the institution.

Decolonization did not lead countries to choose either of these paths immediately. Rather, many of the new states asked for time to plan their future commercial policy. The Contracting Parties "considered it desirable that, in the period between the acquisition of autonomy and the final decision on relations with the General Agreement, the trade relations between the newly independent countries and the contracting parties continue to be governed by the General Agreement." 12 Consequently, they resolved to apply the GATT de facto in relations with the new territory, provided the territory continued to apply the GATT de facto in relations with them. This allowed the newly independent states "to benefit from, and to apply on a reciprocal basis, the provisions of the GATT" even though they were not formal members. ${ }^{13}$ The period of de facto membership extended for a consid-

10. Most members did apply the GATT to their colonies, although France excepted Morocco and Jamaica was not part of the UK's original list of nonmember participants. See Tomz, Goldstein, and Rivers 2005 for a longer exposition of the actions of each colonial power. That paper uses Rose's 2004 data and an expanded concept of membership. This paper, in comparison, relies on a new and expanded data set, which causes some of our estimates to differ.

11. GATT, Basic Instruments and Selected Documents (hereafter BISD) 10S/73.

12. GATT document C/130 (28 June 1984), 2.

13. GATT document L/2757 (8 March 1967), 2. 
erable period of time. For some countries, only the threat of being excluded from the new WTO prodded them into formal accession. ${ }^{14}$ Participation during this de facto period is a second important form of nonmember involvement.

There were few differences between de facto and formal members. De facto participants received MFN treatment, were invited to multilateral trade negotiations, and could observe the annual GATT sessions. They could not vote, but this was of limited importance because the organization typically did not make decisions by voting, and because the economic benefits of GATT stemmed from MFN, not from votes within the organization. ${ }^{15}$ Thus, de facto participants gave and received the same core rights as formal members, and one would expect their trade flows to be affected in much that same way as formal members.

A third type of nonmember participation existed because the Contracting Parties allowed states to accede provisionally while continuing to negotiate for full membership. Japan, for example, became a formal member in 1955 but the Contracting Parties declared as early as 1953 that, "pending the conclusion of tariff negotiations with Japan ... the commercial relations between the participating contracting parties and Japan shall be based upon the General Agreement." 16 The Contracting Parties made similar arrangements for Switzerland (1958), Israel (1959), Tunisia (1959), Yugoslavia (1959), Argentina (1960), Egypt (1962), Iceland (1964), the Philippines (1973), and Colombia (1975). As with the de facto category, provisional members could not vote or fully use dispute settlement procedures, but they gave and received market access just like formal members.

In summary, these nonmember participants received the core rights of the GATT/ WTO, that is, access to other markets on MFN terms, and they reciprocated that right to other members of the organization. Nonmember participants should, therefore, be included in any analysis of the effects of the GATT/WTO. One cannot say whether and to what extent the organization affected commerce without a careful analysis of which nations were subject to its rules.

14. The maximum allowable duration of de facto status changed over time. The first countries to enter de facto status were Laos and Cambodia, which gained independence in 1949 and 1953, respectively. By late 1957 neither had decided whether to formalize its participation, prompting the Contracting Parties to set deadlines. In two cases (Laos and Guinea) deadlines passed and de facto status expired, but in other cases the new states enlisted as formal members or secured extensions to their de facto status. Eventually the Contracting Parties stopped imposing deadlines and allowed de facto participation to continue indefinitely. See BISD 15S/64; L/3457 (9 November 1970), 1. The practice ended only with the creation of the WTO, which eliminated the possibility of de facto participation by requiring countries to accede or lose benefits.

15. "In the normal course of business, the fact that it was not possible, from a strictly legal point of view, to give full voting rights" to nonmember participants "was not very important as the Contracting Parties did not usually proceed to a formal vote in reaching decisions; generally the Chairman took the sense of the meeting," and a nonmember participant "would have the same opportunity as contracting parties to express its opinion"; GATT document SR. 14/10 (10 June 1959), 120. De facto participants had no right to assistance in resolving disputes between themselves and contracting parties regarding the interpretation of the agreement.

16. BISD $2 S / 31$. 


\section{Overestimating the Rights and Obligations of Formal Members}

Focusing narrowly on signatories would not only understate the GATT/WTO's scope by overlooking nonmember participants, but also overstate its legal reach by not accounting for opt-out provisions. Many trade agreements contain safeguard clauses that allow countries to reinstate protectionism under certain conditions. The GATT/WTO went further: members could opt not to apply the agreement in relations with certain other members. Thus, even formal members were not necessarily bound to follow the agreement all the time.

The primary opt-out clause in the GATT was Article XXXV. ${ }^{17}$ A state could choose not to extend rights to a new member if: "(a) the two contracting parties have not entered into tariff negotiations with each other, and (b) either of the contracting parties, at the time either becomes a contracting party, does not consent to such application." These provisions allowed one signatory to limit its trade relations with any entering member, potentially undermining the impact of membership.

The opt-out clause was sometimes invoked for economic reasons and other times used for political purposes, such as the U.S. decision to eschew trade with certain communist countries. ${ }^{18}$ In all, more than sixty countries resorted to Article XXXV or the equivalent provision of the WTO agreement. By doing so, they limited the economic rights of approximately thirty countries. When Japan acceded in 1955 , for example, fourteen contracting parties used Article XXXV against it. The effective number was considerably higher, because colonial powers invoked Article XXXV not only for themselves but also for their overseas territories. ${ }^{19}$

In summary, some signatories had less standing-narrower rights and obligations - than others. Even more commonly, countries without formal status received the full benefits of the trade regime. Our empirical analysis below confirms that the concept of standing is essential to understanding the GATT/WTO.

\section{Embeddedness: The GATT/WTO in the Context of Other Commercial Agreements}

The international system is complex, and most countries participate in a wide range of military, economic, and social institutions. One study, which focused exclu-

17. Article XIII of the WTO agreement resembles Article XXXV of GATT.

18. Opt-out clauses, if regularly invoked, would undermine the purposes of the regime by restricting trade flows. Their existence, however, may be a political necessity. Rosendorff and Milner 2001, 831 suggest that safeguard clauses such as Articles XXXV and XIX in the GATT/WTO may be "an efficient equilibrium under conditions of domestic uncertainty."

19. Other GATT exceptions included Article XI (the sheltering of agricultural quantitative restrictions), Article XVI (toleration of export subsidies for primary products), and Article XX (allowing countries to use trade restriction in support of health and safety standards). The GATT also permitted countries to restrict imports to protect the domestic environment under Article XX(g) and Article XX(b). These exceptions were consequential but less pervasive since they affected only particular products in specific countries. 
sively on formal membership, found that even the "least integrated" country in the world belonged to fourteen intergovernmental organizations, and that all but two were signatories to at least 100 IGOs. ${ }^{20}$ Moreover, these estimates pertain only to selected agreements, all of which involve intergovernmental bodies with permanent staffs. A much larger set of international agreements gives rights and obligations without establishing administrative bodies. The network of international institutions is remarkably dense.

Likewise, the GATT/WTO is embedded in a system of other trade agreements, including PTAs. As the number of PTAs grew in the 1980s and 1990s, scholars worried that such agreements would undermine the GATT/WTO system. PTAs seemed problematic because they excluded countries; any benefit accruing to a PTA would be even greater if expanded multilaterally through the GATT/WTO. ${ }^{21}$ Some also feared that as PTAs proliferated, so too would the number of rent seekers who would lobby for protection from both PTAs and the GATT/WTO. ${ }^{22}$ Mansfield and Reinhardt found that the GATT/WTO stimulated the growth of PTAs to furnish "states with insurance against ... conditions within GATT/WTO that could threaten their economic interests." 23

In their study of the relationship between the GATT/WTO and other trade agreements, Subramanian and Wei propose a hierarchy hypothesis: the effect of the GATT/WTO depends on the presence or absence of higher-order agreements. The international system abounds with many commercial pacts, some more generous than others. If two countries strike an agreement that supersedes the GATT/WTO, by giving preferences even more generous than what the GATT/WTO provides, the effect of the GATT/WTO may be minimal. According to Subramanian and Wei, free trade agreements "represent the culmination of trade integration, whereas the WTO represents some intermediate way station." Thus, two countries that belong not only to the GATT/WTO but also to a common FTA "would not be expected to trade more with each other than if they [were] simply members of a common FTA but not members of the WTO." 24

Subramanian and Wei do not directly test their hierarchy hypothesis, however. Using a gravity model to estimate the effect of the GATT/WTO, they define trade agreements "mutually exclusively in order to be able to isolate the impact of each, purged of any "contamination' from the other." The GATT/WTO dummy variables in their analysis are "coded to exclude country-pairs belonging to the same FTA/customs union agreement or involved in GSP relationships." ${ }^{25}$ This imposes the hierarchy hypothesis on the data.

20. Shanks, Jacobson, and Kaplan 1996, 611.

21. Bhagwati 1992.

22. Krueger 1997.

23. Mansfield and Reinhardt 2003.

24. Subramanian and Wei forthcoming, 10.

25. Ibid., 9. 
Like Subramanian and Wei, we wish to understand the effects of multiple memberships in trade agreements. But as opposed to their study, we do not assume agreements are necessarily hierarchical. Below, we offer a formal test of the hierarchy hypothesis by estimating the effect of the GATT/WTO not only in the absence, but also in the presence, of other commercial pacts: colonial trade preferences, bidirectional preferential trade agreements, and unidirectional agreements.

\section{Colonial Preferences}

The GATT/WTO was founded on the basic principle of nondiscrimination, which the founders made operational by requiring each participant to treat others as a most-favored nation. According to Article I, "any advantage, favor, privilege or immunity granted by any contracting party to any product originating in or destined for any other country shall be accorded immediately and unconditionally to the like product originating in or destined for the territories of all other contracting parties." To this day, the right to MFN treatment is arguably the principal benefit of participation in the GATT/WTO.

Nevertheless, the GATT/WTO permitted the existence of other, more generous trade agreements. This seeming inconsistency reflected the underlying reality of trade relations at the end of World War II. Many founding members had responded to the Great Depression by creating colonial trade zones with common currencies and relatively low import barriers. The United States complained that such arrangements were inconsistent with the norm of nondiscrimination, but it could not persuade its counterparts in Geneva to extend colonial tariff rates to everyone, nor did it succeed in outlawing colonial preferences altogether. The final version of Article I contained an explicit waiver, allowing the British, French, and Benelux countries to retain their imperial tariff preferences.

The GATT/WTO was, therefore, superimposed on a preexisting network of stronger but geographically more limited colonial agreements. To understand the effect of this history of colonization, we estimate the trade flows between members of the same colonial orbit and compare them to flows generated by GATT/ WTO participation.

\section{Preferential Trade Agreements}

The GATT/WTO's founders not only accepted colonial relationships as legitimate deviations from the MFN principle, but also opened the door to future PTAs. Article XXIV allowed contracting parties to form customs unions or free trade areas, provided they met GATT/WTO standards for liberalization and product coverage. Contracting parties have taken advantage of this opportunity by notifying more than 100 agreements to the GATT/WTO over the past half-century. A standing committee examines each PTA, but to date none has been judged inconsistent with the rules of the organization. 
Much has been written about the effects of joining a PTA. ${ }^{26}$ We take the next natural step by studying the interaction of regionalism with GATT/WTO participation.

\section{Unidirectional Trade Agreements: The Generalized System} of Preferences (GSP)

A third exception to the norm of nondiscrimination emerged in the 1960s, when GATT/WTO members established the legitimacy of special and differential benefits for the developing world. Two reforms emerged. Developing countries were allowed to form PTAs without meeting the standard requirement of covering substantially all trade, and they were granted asymmetric access to the markets of industrialized states. The latter change flowed from discussions at the United Nations Conference on Trade and Development (UNCTAD), where participants argued that poor countries could advance economically by increasing exports of semi-manufactured goods to richer countries. The GSP is the most common of these agreements, but other unidirectional pacts exist, most notably the Lomé agreement between European nations and a number of less-industrialized countries.

In 1966 Australia became the first contracting party to establish a GSP for poor countries. It requested and received a waiver to deviate from the MFN principle by offering privileged access to manufactured products from the developing world. Other countries followed suit in 1971, when the Contracting Parties approved a comprehensive ten-year exception from Article I to allow "generalized, nonreciprocal" preference schemes for developing countries. The waiver became permanent in 1979.

Few researchers have attempted to estimate the overall effect of the GSP. One recent study by Ozden and Reinhardt finds that the U.S. GSP is not associated with an increase in trade. ${ }^{27} \mathrm{We}$ expand their analysis by surveying all preference schemes in a variety of political contexts. This allows us to quantify the effect of GSP-type preferences around the world, and to study the interaction between the GATT/WTO and the GSP.

To summarize, the concepts of standing and embeddedness can help one understand when and for whom international institutions matter. In the domain of trade, the GATT/WTO should promote exchange not merely among formal members,

26. Viner 1950 introduced criteria for evaluating PTAs: agreements can be said to increase welfare if they lead to more trade creation than trade diversion. His criterion was subsequently used in empirical studies; see, for example, Corden 1976; Bhagwati and Panagariya 1996; Frankel 1997; and Lawrence 1999, most of which found that PTAs increase trade when they lead to significant reductions in trade barriers and when the signatories trade extensively with each other. For recent work on the political origins of PTAs, see Mansfield and Reinhardt 2003; and Mansfield and Milner 1999.

27. Ozden and Reinhardt 2005. 
but more broadly among all countries and territories with legal standing. Moreover, the GATT/WTO should be evaluated along with other trade agreements. The remainder of the article addresses these propositions.

\section{Statistical Model}

We employ the workhorse model of international trade-the gravity model-to estimate the effects of postwar trade agreements. To study the effects of the GATT/ WTO, we augment the baseline gravity specification with indicators for GATT/ WTO participation:

$$
\begin{aligned}
\log M_{i j t}= & \beta_{0}+\beta_{1} \log \left(G D P_{i t} G D P_{j t}\right)+\beta_{2} \log d_{i j} \\
& +\beta_{3} \text { GATTWTO }_{i j t}+\beta_{4} X_{i j t}+\varepsilon_{i j t},
\end{aligned}
$$

where $i$ and $j$ index countries, $t$ indexes years, $M_{i j t}=$ imports by country $i$ from country $j$ in year $t, G D P_{i t}=$ gross domestic product of country $i$ in year $t, d_{i j}=$ distance between country $i$ and country $j$, GATTWTO $O_{i j t}=$ indicators of standing in GATT/WTO for countries $i$ and $j$ in year $t, X_{i j t}=$ other control variables, and $\varepsilon_{i j t}$ is an error term.

The log linear functional form means that the coefficients are interpretable as point elasticities. For example, if $\beta_{2}=-1$, a 1 percent increase in distance between countries is associated with approximately a 1 percent decrease in trade; these effects are independent of the units of measurement of the variables. When the regressor is a dummy variable, such as an indicator for participation in the GATT/ WTO, the effect is calculated as an arc elasticity, $e^{\beta}-1$, which will be close to the point elasticity if $\beta$ is small. ${ }^{28}$

This approach, while standard, does not capture all potential effects of the GATT/WTO. First, as is common in the literature, we model only the contemporaneous effects of participation. It is plausible that the effects of participation occur slowly and are not fully realized for a period of years. The contemporaneous participation dummy variable measures the average difference in trade in the periods before and after the countries in the dyad joined the GATT/WTO. This will, to some extent, underestimate the effects of participation, though the bias should not be large. Second, if increases in trade lead to subsequent increases in

28. The point elasticity is defined as

$$
\frac{\partial \log M}{\partial \log X}=\frac{\partial M}{\partial X} \frac{X}{M} \cong \frac{\Delta M / M}{\Delta X / X} .
$$

The approximation is good for small changes in $X$. When $X$ is a dummy variable, the approximation is often poor, so we use the arc elasticity discussed in the text. 
GDP, these will not be attributed to GATT/WTO, which might be responsible for the initial increase in trade. This is a problem of computing dynamic multipliers, which we will not take up here. Finally, GDP is endogenously determined (since exports are a component of GDP), which can cause bias in the estimate. Our treatment, however, is consistent with usual econometric practice in estimating gravity models.

Most of the specifications reported in this article include fixed effects (FE) for years and directed dyads. This enables us to control for certain kinds of unmeasured factors. For example, an event such as an oil price shock that has a similar impact on all countries can be controlled by including fixed effects for time periods. Similarly, by using a model that employs fixed effects for directed dyads we are able to control for unmeasured factors that do not vary over time. For instance, trade between countries using the same measurement system (for example, metric or English) might be higher than that between countries that use different measurement systems. Instead of collecting data on a myriad of minor factors such as these, we use dyadic fixed effects to account for unobserved heterogeneity and delete any variables that do not vary over time, such as distance and common language.

The primary advantage of FE estimates is robustness to certain forms of misspecification and endogeneity. Their main disadvantage is inefficiency, since they do not exploit cross-sectional variation between dyads. Given the large size of this data set, inefficiency is not too serious a problem. Unless the proportion of variance between units is very large (which it is not), there is sufficient withindyad variation to obtain good estimates using FE. ${ }^{29}$

In some cases, we wish to estimate time-varying effects for the GATT/WTO and other agreements by making the effect sizes a function of time. One straightforward approach is to divide the sample into subperiods and to estimate either separate models or separate sets of coefficients for each subperiod. The disadvantage of this approach is that the choice of subperiods is arbitrary and the estimated models imply implausible discontinuities in effect sizes at the period breaks. A better approach, which allows for a smooth evolution of effect sizes over time, is the method of cubic splines. The basic idea is to fit third degree polynomials in time that differ by subinterval but are joined at the period breakpoints, known as "knots." We force the effects of the first and second derivatives of the spline function to agree at the knots. Also, because splines behave poorly in the tails, we follow the suggestion of Stone to make the function linear in the first and last subintervals. ${ }^{30}$

29. There are also theoretical reasons to prefer a fixed-effect model; see Feenstra 2004, 161-63. Anderson and van Wincoop 2003 derive a gravity-type specification from a model with each country producing a single differentiated good, CES utilities, and market clearing. Their model implies the presence of a "multilateral resistance" term that can be approximated using country and time fixed effects. Moreover, Baier and Bergstrand forthcoming conclude that, for research on trade agreements, the best approach to dealing with endogenous unit effects is either fixed effects or differencing.

30. Stone 1994. 


\section{Data}

We estimate the gravity model using a new data set that contains the annual value of trade between all pairs of countries in the world, measures of involvement in the GATT/WTO and other trade agreements, and a set of economic and political control variables. The main data set begins in 1946, two years before the General Agreement went into force, and extends through 2004. Unlike previous analyses such as Rose's, we have observations prior to the establishment of the GATT/ WTO. ${ }^{31}$ In FE models estimated with post-1947 data, the initial joiners are effectively dropped when estimating the impact of the GATT/WTO, since the participation variables are constant for them beginning in 1948. By extending the data set we overcome this limitation. Before turning to the empirical findings, we briefly describe the data on which they are based.

\section{Measures of Trade}

Data on trade flows come from the International Monetary Fund (IMF), which compiles the official commercial reports of most countries and publishes them in the Direction of Trade Statistics (DOTS). ${ }^{32}$ For the years 1946 and 1947, which are not included in the DOTS, we collected trade data from individual country statistical yearbooks. To assure the hand-collected data were consistent with the DOTS, we compared the 1948 data in the yearbooks with figures found in the DOTS and used country yearbook data only when the two sources agreed closely. ${ }^{33}$

In any given year, the DOTS and country yearbooks provide up to four numbers for each pair of countries: the report by country $i$ of its imports from and exports to country $j$, and the report by country $j$ of its imports from and exports to country $i$, denoted $M_{i j t}^{(i)}, X_{i j t}^{(i)}, M_{j i t}^{(j)}$, and $X_{j i t}^{(j)}$, respectively, where superscripts denote the reporting country. Most researchers regard import statistics as more reliable than export statistics, since countries have a strong incentive to track goods entering their country, if for no other reason than to apply tariffs and nontariff barriers. We therefore rely on each country's tabulation of its own imports $\left(M_{i j t}^{(i)}\right.$ and $M_{j i t}^{(j)}$ ) whenever possible.

When either $M_{i j t}^{(i)}$ or $M_{j i t}^{(j)}$ is missing, we use partner reports $X_{j i t}^{(j)}$ or $X_{i j t}^{(i)}$ to plug holes in the data set. In principle, we should have $M_{i j t}^{(i)}=X_{j i t}^{(j)}$ and $X_{i j t}^{(i)}=M_{j i t}^{(j)}$, since the value that country $i$ records in its import ledger should equal the number that country $j$ records in its export books. In practice, however, country reports differ for a variety of reasons including different bases of valuation and timing. The UN recommends that each country exclude the cost of insurance and freight

31. Rose 2004.

32. IMF 2005.

33. We dropped any hand-collected data that were not within 5 percent of the values found in the DOTS for 1948. 
in export figures but include such fees in import figures. As a consequence, the imports reported by a country tend to exceed the exports reported by its trading partner. We follow the standard UN/IMF practice of estimating the missing import data by taking the partner's exports (reported free on board) and adding 10 percent to reflect the cost of insurance and freight. Approximately one-tenth of the import data in our final sample arose through this imputation procedure.

\section{Size and Distance}

The explanatory variables in a gravity model include the GDP of each partner in each dyad, as well as the physical distance between them. For GDP we turned first to the 2005 edition of the World Bank's World Development Indicators, which gives GDP in U.S. dollars for most countries in the world from 1960 to the present. We then extended the series backwards to 1946, using U.S. dollar figures from the Penn World Tables, the United Nations, the Oxford Latin American Economic History Database, and the IMF International Financial Statistics. In a few cases, we used the GDP indices from Maddison and his colleagues at the University of Groningen to complete the data set. ${ }^{34}$ We could not obtain consistent GDP data for several small or dependent states, such as the Netherlands, Antilles, the Faeroe Islands, Martinique, Guadeloupe, and Gibraltar, and therefore dropped them from the analysis.

We define distance between countries as the number of miles from the geographic center, or centroid, of the exporter to the geographic center of the importer. Coordinates for the centroid of each country come from the 2005 edition of the CIA World Factbook and the Gazetteer of Conventional Names. Following other researchers, we computed distances according to the great circle formula, which assumes the earth is a sphere and gives the minimum distance along the surface. This is admittedly a rough proxy for distance, since most goods move along available land, sea, and air routes, rather than traveling "as straight as the crow flies." In the absence of more direct measures of shipping costs, though, it makes sense to rely on great circle distance, which previous researchers have shown to be a good predictor of trade flows.

\section{Standing and Embeddedness}

The standard gravity variables-GDP and distance-provide a baseline for evaluating the effects of our key explanatory variable, involvement in the GATT/ WTO. As discussed above, we classify countries as formal members, nonmember participants (those with colonial, de facto, or provisional standing), and nonparticipants. Our principal sources of data on legal standing include the analytical

34. See Maddison 1995, 2001, and 2003; and Conference Board/Groningen Growth and Development Centre 2003. 
indexes of the GATT/WTO and official documents from the organization's archives in Geneva.

Our data set contains new measures of legal standing not only in the GATT/ WTO, but also in other trade agreements. Specifically, we collected data on who designated whom as a beneficiary of the GSP, and in what years the benefits applied. Our GSP indicator varies considerably across dyads and over the years, since grantors inaugurated their GSP schemes at different times and changed the list of beneficiaries periodically. This measure, compiled from official reports of GATT, UNCTAD, the European Union, and the grantor governments, is substantially more accurate and comprehensive than measures in previous analyses. Nonetheless, there is room to improve the measure by taking into account heterogeneity in the scope and degree of benefits. Each grantor country not only sets its list of beneficiaries, but also selects the products to which the preferences apply and defines the margin of tariff preferences for those products. Because our data are aggregated across all goods, we have not attempted to deal with differences in GSP preferences at the product level.

Similarly, we have attempted to catalogue all preferential trading arrangements in the postwar period. Although it is hard to verify whether we now have a comprehensive list of PTAs, our data set includes dozens of reciprocal and nonreciprocal agreements that were not part of earlier studies. As with the GSP, some PTAs are more generous and encompass more products than others. A natural extension of the research would be to code not only the existence but also the strength of PTAs. Overall, though, our new measures of GSP and PTAs should allow us to compare the effects of GATT/WTO with other commercial arrangements.

Finally, we recorded the presence of colonial trading networks in two ways. First, we constructed an indicator of whether country A and country B were in the same "colonial orbit," meaning that one country is a colonizer and the other is its colony or that both countries are current colonies with a common metropole. We are not aware of other research that uses this variable, and we show below that it has a substantial effect on the quantity of trade. We also measure whether two countries had a common colonizer, even after achieving independence. This variable taps the kinds of colonial legacies that might influence trade today.

For models without dyadic fixed effects, we augment the gravity equation by including geographic, cultural and financial variables. Specifically, we measure whether the members of a dyad are islands, landlocked, and adjacent, and whether they share a common language. Data for these variables come primarily from the CIA World Factbook. We rely on Rose for data on currency unions. ${ }^{35}$

\section{The Sample}

Our choice of sample reflects the quality of the available data. The data set is comprised of directed dyads, with country-pairs appearing twice each year, once 
with each country as the importer. We include all countries with at least 1 million people; data on trade flows, GDP, and other key attributes of smaller states were either missing or questionable. Even without these microstates, our data set covers not only the core economies, but also the vast majority of peripheral ones (see the Appendix, which lists the 161 countries in our final sample). ${ }^{36}$ Likewise, we focus on trade flows of at least $\$ 100,000$ a year in 1967 dollars, the base year for our deflator. Smaller trade flows are suspect because they can be perturbed by even minor reporting errors, and because-due to rounding and reporting conventions in the DOTS - there is no way to distinguish between miniscule levels of trade, the absence of trade, and missing data, all of which are often represented by zeros in the data set. Our final data set comprises 381,656 directed dyads.

\section{Empirical Results}

Our analysis confirms that the GATT/WTO has indeed transformed postwar trade, though both the timing and the distribution of the effects are surprising.

\section{The Effects of Participation}

The claim that membership in the GATT/WTO increases trade would seem unremarkable, except that the leading comprehensive quantitative study reaches the opposite conclusion. ${ }^{37}$ Using the gravity framework described above, Rose finds no evidence of increased trade among formal members of the GATT/WTO. When we replicate his analysis with our data, we obtain similar results. The first equation in Table 1 shows that, in a model without dyadic fixed effects, formal GATT/ WTO membership reduces trade; the impact becomes negligible when the model is estimated with FE. ${ }^{38}$ The positive effects of being in currency unions and reciprocal PTAs are evident although, as opposed to Rose who argues that GSP increases trade, we estimate a negative coefficient for GSP. In general, however, these results appear to confirm Rose's finding that formal GATT/WTO membership did little to increase trade.

The main problem with Rose's analysis is his reliance on formal membership in the GATT/WTO and his neglect of other forms of participation. Table 2 uses our corrected measure of participation, which includes all nations that were bound by

36. The results are similar when we use all available data, rather than restricting attention to countries with at least 1 million people.

37. Rose 2004.

38. In contrast to Rose 2004, we estimate models for directional trade flows, instead of the average of imports and exports. Rose also uses country fixed effects (while we use directed dyad fixed effects) and some variables, such as GDP per capita and distinctions between colonies and former territories, that did not have significant effects in preliminary regressions. None of these differences affect the results reported here. 
TABLE 1. The apparent irrelevance of GATT/WTO membership

\begin{tabular}{|c|c|c|}
\hline & $\begin{array}{l}\text { Includes } \\
\text { year } \\
\text { effects }\end{array}$ & $\begin{array}{l}\text { Dyad and } \\
\text { year } \\
\text { effects }\end{array}$ \\
\hline Both formal GATT/WTO members & $\begin{array}{r}-.07 \\
(.03)\end{array}$ & $\begin{array}{c}.07 \\
(.02)\end{array}$ \\
\hline Only one formal GATT/WTO member & $\begin{array}{c}-.21 \\
(.03)\end{array}$ & $\begin{array}{r}-.02 \\
(.02)\end{array}$ \\
\hline Reciprocal PTA & $\begin{array}{l}.33 \\
(.03)\end{array}$ & $\begin{array}{l}.35 \\
(.02)\end{array}$ \\
\hline Nonreciprocal PTA & $\begin{array}{l}.14 \\
(.03)\end{array}$ & $\begin{array}{r}-.07 \\
(.03)\end{array}$ \\
\hline GSP & $\begin{array}{r}-.10 \\
(.02)\end{array}$ & $\begin{array}{r}-.10 \\
(.02)\end{array}$ \\
\hline Currency union & $\begin{array}{l}1.01 \\
(.08)\end{array}$ & $\begin{array}{l}.49 \\
(.09)\end{array}$ \\
\hline Colonial orbit & $\begin{array}{l}1.75 \\
(.10)\end{array}$ & $\begin{array}{l}.88 \\
(.08)\end{array}$ \\
\hline Log product real GDP & $\begin{array}{c}.77 \\
(.01)\end{array}$ & $\begin{array}{l}.67 \\
(.01)\end{array}$ \\
\hline Log of distance & $\begin{array}{c}-.71 \\
(.01)\end{array}$ & \\
\hline Common language & $\begin{array}{l}.36 \\
(.03)\end{array}$ & \\
\hline Land border & $\begin{array}{l}.58 \\
(.06)\end{array}$ & \\
\hline Number landlocked & $\begin{array}{r}-.14 \\
(.02)\end{array}$ & \\
\hline Number of islands & $\begin{array}{l}.24 \\
(.03)\end{array}$ & \\
\hline Log product land area & $\begin{array}{r}-.10 \\
(.00)\end{array}$ & \\
\hline $\begin{array}{l}\text { Standard error of the regression } \\
R^{2}\end{array}$ & $\begin{array}{c}1.42 \\
.61 \\
381656\end{array}$ & $\begin{array}{c}.94 \\
.84 \\
381656\end{array}$ \\
\hline
\end{tabular}

Notes: Estimates from ordinary least squares (OLS) regression. For both models, the unit of observation is the directed dyad and the dependent variable is the natural log of imports (measured in 1967 U.S. dollars). The data cover fifty-nine years and 17,359 directed dyads. Robust standard errors, clustered by directed dyad, appear in parentheses. Both models include yearspecific dummy variables, which are not shown. The second model adds fixed effects for directed dyads.

GATT/WTO rules and obtained GATT/WTO privileges. The first equation in Table 2 allows the effect of participation to vary depending on whether a country is a formal member or a nonmember participant. The second constrains the effects to be the same for formal members and nonmember participants. The estimates in Table 2 provide a starkly different view of the role of the trade regime than that in 
TABLE 2. The Effect of Participation in the GATT/WTO

\begin{tabular}{|c|c|c|}
\hline & Full model & $\begin{array}{l}\text { Restricted } \\
\text { model }\end{array}$ \\
\hline \multicolumn{3}{|l|}{ Both participate in the GATT/WTO } \\
\hline Both formal members & $\begin{array}{l}.34 \\
(.03)\end{array}$ & \\
\hline Both nonmember participants & $\begin{array}{l}.45 \\
(.07)\end{array}$ & $\begin{array}{l}.35 \\
(.03)\end{array}$ \\
\hline Formal member and nonmember participant & $\begin{array}{l}.38 \\
(.04)\end{array}$ & \\
\hline \multicolumn{3}{|l|}{ Only one participates in the GATT/WTO } \\
\hline Formal member & $\begin{array}{l}.20 \\
(.03)\end{array}$ & \\
\hline & & $(.03)$ \\
\hline Nonmember participant & $\begin{array}{l}.17 \\
(.04)\end{array}$ & \\
\hline Reciprocal PTA & $\begin{array}{l}.34 \\
(.02)\end{array}$ & $\begin{array}{l}.34 \\
(.02)\end{array}$ \\
\hline Nonreciprocal PTA & $\begin{array}{c}-.05 \\
(.03)\end{array}$ & $\begin{array}{c}-.05 \\
(.03)\end{array}$ \\
\hline GSP & $\begin{array}{r}-.10 \\
(.02)\end{array}$ & $\begin{array}{c}-.10 \\
(.02)\end{array}$ \\
\hline Currency union & $\begin{array}{l}.50 \\
(.09)\end{array}$ & $\begin{array}{l}.49 \\
(.09)\end{array}$ \\
\hline Colonial orbit & $\begin{array}{l}.81 \\
(.08)\end{array}$ & $\begin{array}{c}.84 \\
(.08)\end{array}$ \\
\hline Log product real GDP & $\begin{array}{l}.66 \\
(.01)\end{array}$ & $\begin{array}{l}.66 \\
(.01)\end{array}$ \\
\hline Standard error of the regression & .94 & .94 \\
\hline$R^{2}$ & .84 & .84 \\
\hline$N$ & 381,656 & 381,656 \\
\hline
\end{tabular}

Notes: Estimates from ordinary least squares (OLS) regression. For both models, the unit of observation is the directed dyad and the dependent variable is the natural log of imports (measured in 1967 U.S. dollars). The data cover fifty-nine years and 17,359 directed dyads. Robust standard errors, clustered by directed dyad, appear in parentheses. The restricted model constrains all three measures of "both participate in GATT" to have equal effects and constrains both forms of "only one participates in GATT" to have equal effects. Both models include fixed effects for directed dyads and years.

Table 1. Both formal members and nonmember participants trade substantially more than nonparticipants. The effect is statistically significant, and is about the same for formal members as for nonmember participants. ${ }^{39}$

39. The robust $F$ test for whether the effects are the same for formal members and nonmember participants is not significant $(F=2.18$ with 3 and 17,358 degrees of freedom; $p=.09)$. Thus, the restriction imposed in the second equation of Table 2 cannot be rejected by the data. 
TABLE 3. Increase in trade among GATT/WTO participants

\begin{tabular}{lccc}
\hline & $\begin{array}{c}\text { Formal } \\
\text { member }\end{array}$ & $\begin{array}{c}\text { Nonmember } \\
\text { participant }\end{array}$ & Nonparticipant \\
\hline Formal member & $41 \%$ & $46 \%$ & $22 \%$ \\
Nonmember participant & & $56 \%$ & $19 \%$ \\
Nonparticipant & & $0 \%$ \\
\hline
\end{tabular}

Notes: Entries are the estimated percentage increase in trade for a pair of countries (with GATT/WTO participation given by the row and column labels), relative to when neither country participates. Each effect is calculated as an arc elasticity, $e^{\hat{\beta}}-$ 1 , where $\hat{\beta}$ is the appropriate parameter estimate from the full model in Table 2.

Table 3 summarizes the results from Table 2 in terms of the percentage increase in trade for formal members and nonmember participants, compared with those who did not participate in the GATT/WTO. ${ }^{40}$ Among two formal members, trade increased 41 percent, as compared with trade among pairs of nonparticipants. When one country was a formal member and the other a nonmember participant, trade increased by about 46 percent. We estimate the trade effect when both countries were nonmember participants to be 56 percent. The overall effect of GATT/ WTO participation (based on the second equation in Table 2) was to increase trade about 43 percent among countries in the organization, relative to pairs of nonparticipants.

Importantly, the GATT/WTO increased trade for both formal members and nonmember participants. When nonmember participation is taken into account, the effect of formal membership becomes large (about 41 percent higher than among nonparticipants) and statistically significant. The discrepancy between our estimate and Rose's arises because he pooled nonmember participants with nonparticipants. His estimate for formal membership can be viewed as a combination of two effects: (1) The difference between the effect for formal members and nonmember participants, which is negative (46 percent -56 percent $=-10$ percent); and (2) the difference between the effect for formal members and nonparticipants (46 percent). Because of pooling, the combined estimate is close to zero or even negative. ${ }^{41}$

Table 2 also confirms the importance of PTAs, colonialism, and currency unions, all of which are associated with higher trade. GSP and nonreciprocal PTAs, on the other hand, continue to have negative signs, although only the GSP coefficient is significantly different from zero.

40. We have translated the regression coefficients into percentage change in trade flows using the formula $e^{\beta}-1$.

41. Pooled regression estimates are matrix-weighted averages of the unpooled estimates and do not necessarily lie in the convex hull of the unpooled estimates. See Chamberlain and Leamer 1976. 
We next investigate whether the benefits of participating in the GATT/WTO have changed over time. It is possible that the trade-enhancing effects of the agreement were due mainly to liberalization in the earliest years. To explore this possibility we examine trade after each negotiating round. The GATT/WTO has completed eight rounds of trade talks, varying in length from a few months to eight years. Each round closed with a set of agreements shared by all members. Early rounds focused on reducing tariffs, whereas later rounds attempted to halt the use of nontariff barriers.

Table 4 provides separate estimates of the GATT/WTO effect by negotiating round. ${ }^{42}$ Each round apparently contributed to trade, with larger effects when both countries in a dyad participated and smaller (but still positive) effects when only one participated. The impact of participation diminished gradually and became negligible with the establishment of the WTO after the Uruguay Round. By that time, only a handful of countries remained outside the regime: a few Middle Eastern nations, formerly Communist countries, and microstates. This makes our estimate of the GATT/WTO effect in the final period imprecise and questionable.

With the exception of the most recent period, the results in Table 4 support our initial hypothesis about the positive effects of the GATT/WTO. When both countries participated in the agreement, the stimulus to trade varied from a huge 136 percent in the first two years of the organization, to 93 percent after the Torquay Round, 26 percent after the Kennedy Round, and 24 percent from the Tokyo Round. Rose, who had no data before 1948, found that the institution exerted a large but statistically insignificant effect before the Annecy Round. ${ }^{43}$ With our expanded data set, we, too, find a large GATT/WTO effect before Annecy, but the estimate is more precise (as indicated by the smaller standard error) and now statistically significant. Overall, the organization's effect was largest in the early years, when the number of members was smallest and countries outside the regime retained historically high barriers to trade.

We further find that the GATT/WTO increased trade for both industrial and nonindustrial countries. Table 5 reports the estimated impact of participation for countries classified according to the IMF standard for industrialization. ${ }^{44}$ Our estimates suggest that the GATT/WTO expanded commerce by more than 70 percent when both trading partners were industrial nations, by about 45 percent when trade was between an industrial and a developing economy, and by approximately 33 percent between developing countries that had standing in the organization. Moreover, the effect is large compared with most other agreements. Over the entire period studied, industrial nations gained more from participation in the GATT/

42. In Figure 1 below, we provide alternative estimates of GATT/WTO effects over time using restricted cubic splines.

43. Rose 2004.

44. To check the robustness of our findings, we estimated the model for all dyads, not just ones in which the countries had at least 1 million people and $\$ 100,000$ in trade. In this larger sample, GATT/WTO participation increased trade of nonindustrialized nations by 55 percent, compared with nonparticipants. 
TABLE 4. Effects by GATT/WTO negotiating round

\begin{tabular}{lcc}
\hline & $\begin{array}{c}\text { Both } \\
\text { participate } \\
\text { in GATT/WTO }\end{array}$ & $\begin{array}{c}\text { One } \\
\text { participates } \\
\text { in GATT/WTO }\end{array}$ \\
\hline Before Annecy Round (1949) & .86 & .15 \\
Annecy to Torquay Round (1951) & $(.08)$ & $(.06)$ \\
Torquay to Geneva Round (1956) & .58 & .17 \\
Geneva to Dillon Round (1961) & $(.06)$ & $(.05)$ \\
Dillon to Kennedy Round (1967) & .66 & .22 \\
Kennedy to Tokyo Round (1979) & $.06)$ & $(.06)$ \\
Tokyo to Uruguay Round (1994) & .48 & .19 \\
& $(.05)$ & .15 \\
After the Uruguay Round & .33 & $(.05)$ \\
& $(.05)$ & .13 \\
& .23 & $.05)$ \\
& $(.05)$ & $(.05)$ \\
\end{tabular}

Notes: All estimates in the table come from a pooled ordinary least squares (OLS) regression with separate GATT coefficients for each negotiating round. The unit of observation is the directed dyad and the dependent variable is the natural log of imports (measured in 1967 U.S. dollars). The regression involved 381,656 observations, which covered fifty-nine years and 17,359 directed dyads. The model includes fixed effects for directed dyads and years, as well as controls for reciprocal PTAs, nonreciprocal PTAs, GSP, currency union, colonial orbit, and the log product of real GDP. Robust standard errors, clustered by directed dyad, appear in parentheses. The standard error of the regression was .94 , and $R^{2}$ was .84 .

WTO (a 71 percent increase in trade) than they gained from membership in PTAs (34 percent rise in trade). The consequences of the GATT/WTO for nonindustrial countries were smaller, but nonetheless as large as the average impact of PTAs on bilateral trade.

These findings contradict the conventional wisdom that the GATT/WTO did little to spur the trade of developing countries. ${ }^{45}$ Participation appears to benefit all countries, no matter their level of development. How has the organization achieved this outcome when it is well known that developing nations were often asked to make fewer concessions than industrialized nations? A review of the GATT/WTO's history suggests three possible explanations. First, the GATT/ WTO required developing countries to extend MFN tariffs to other participants,

45. Gowa and Kim conclude differently, arguing that the GATT, "had a large, positive, and significant impact on trade between only five of its member states: Britain, Canada, France, Germany, and the United States"; see Gowa and Kim 2005, 454. Subramanian and Wei forthcoming agree with our finding that, contra Rose, the GATT/WTO promoted world trade. They claim, however, that most of the benefits went to the developed world and not to developing nations. We suspect the difference in findings stems from our use of different data and a corrected measure of standing in the GATT/WTO. 
TABLE 5. Effects by income group

\begin{tabular}{|c|c|c|c|}
\hline & $\begin{array}{l}\text { Only } \\
\text { industrial } \\
\text { countries }\end{array}$ & $\begin{array}{l}\text { Industrial with } \\
\text { nonindustrial } \\
\text { country }\end{array}$ & $\begin{array}{l}\text { No } \\
\text { industrial } \\
\text { countries }\end{array}$ \\
\hline Both participate in the GATT/WTO & $\begin{array}{c}.54 \\
(.11)\end{array}$ & $\begin{array}{c}.37 \\
(.06)\end{array}$ & $\begin{array}{l}.28 \\
(.04)\end{array}$ \\
\hline Only one participates in the GATT/WTO & $\begin{array}{l}.25 \\
(.10)\end{array}$ & $\begin{array}{l}.27 \\
(.05)\end{array}$ & $\begin{array}{l}.13 \\
(.04)\end{array}$ \\
\hline Reciprocal PTA & $\begin{array}{l}.29 \\
(.05)\end{array}$ & $\begin{array}{c}.32 \\
(.03)\end{array}$ & $\begin{array}{l}.29 \\
(.03)\end{array}$ \\
\hline $\begin{array}{l}\text { Standard error of the regression } \\
R^{2} \\
N\end{array}$ & $\begin{array}{c}.61 \\
.93 \\
28,971\end{array}$ & $\begin{array}{c}.90 \\
.83 \\
194,963\end{array}$ & $\begin{array}{c}1.02 \\
.74 \\
157,722\end{array}$ \\
\hline
\end{tabular}

Notes: Each column comes from a separate ordinary least squares (OLS) regression in which the unit of observation was the directed dyad and the dependent variable was the natural log of imports (measured in 1967 U.S. dollars). All regressions included fixed effects for directed dyads and years, as well as controls for nonreciprocal PTAs, GSP, currency union, colonial orbit, and the log product of real GDP. The regression for "only industrial countries" covered 594 directed dyads over fifty-nine years; the "industrial with nonindustrial country" regression covered 6,445 directed dyads over fifty-nine years; and the regression with "no industrial countries" covered 10,320 directed dyads over fifty-nine years.

many of whom were previously subject to higher rates. Through the simple application of this principle, the GATT/WTO broadened the geographic coverage of trade. Second, through negotiations, the organization encouraged developing countries to lower and bind their tariffs. In some cases this occurred because developed countries acted on behalf of their colonies; in other cases, developing countries participated directly in the negotiating rounds. Finally, the GATT/WTO gave developing countries access to markets of other participants, including ones that liberalized their trade policies considerably. Thus, even when countries only partially followed the rule of the regime, all members benefited, making the GATT/WTO more than an elite "country club." 46

A similar logic helps explain our finding that the GATT/WTO had a positive effect even when only one member of the dyad participated in the organization. The final column of Table 4 shows that, in all but the most recent time period, dyads with one GATT/WTO participant traded more than dyads without any participants. We see no evidence of trade diversion, even in the early years of limited membership. The positive effect when only one country participates may be due to MFN agreements that predate the GATT/WTO. The United States, for example, maintained MFN treaties with many trading partners at the time of the GATT's creation. As a consequence, U.S. concessions in the GATT/WTO were extended to parties that did not participate in the organization.

Finally, we considered the effects of invoking the key opt-out clause, Article XXXV. The number of invocations in our data set was small: only about 2,200 of 
the more than 380,000 dyads were involved in an Article XXXV action. ${ }^{47}$ When both countries invoked Article XXXV, trade decreased dramatically: by about 75 percent. ${ }^{48}$ A double invocation, however, was a rare event associated with serious political differences between the two states. It was more common to see Article XXXV invoked by only one side, either because one nation feared the trade implications of opening up its markets to a new member, or because broader economic sanctions were in place. In these instances, the invocation of Article XXXV seemed to increase trade by 30 percent, a result we do not regard as plausible.

One possible explanation for the odd estimate involves Japan. The United States propelled Japan's membership into the GATT/WTO despite wide opposition. The result was the systematic invocation of Article XXXV but still flourishing trade, a testament to Japan's ability to develop markets under adverse conditions. We reestimated the model without Japan and obtained more sensible results. The decline in trade when both countries invoked Article XXXV was still large (about 74 percentage points), while the effect when only one country invoked Article XXXV became statistically indistinguishable from zero.

\section{Embeddedness and the Trade Regime}

The evidence presented so far makes a compelling case that the GATT/WTO increased trade. But the institution did not exist in isolation. Is the GATT/WTO inconsequential in the presence of higher-order agreements, as implied by the hierarchy hypothesis, or are trade agreements complementary, each opening up trade perhaps in different areas but not undermining the value of participation in the other? We offer a direct test of whether trade agreements have hierarchical or additive effects.

We consider four types of trade agreements, ordered by their scope and depth. Colonial relationships are at the top of the hierarchy, so their effect is not modeled as conditional on other agreements. Reciprocal PTAs occupy the second tier; we study their effect when countries are in the same colonial orbit, and when they are in different colonial orbits. We put the GATT/WTO in the third position, behind PTAs, and rank nonreciprocal agreements last. ${ }^{49}$

If a hierarchy exists, agreements at the upper end of the hierarchy should have larger effects than those lower in the hierarchy, and agreements lower in the hierarchy should be consequential only when no higher-level agreement is in place. For example, the GATT/WTO should exert no impact on dyads that already have colonial relations or a PTA. Likewise, PTAs should add little to the trade of countries that are already part of the same colonial orbit.

We examine these ideas in Table 6. The first equation imposes the hierarchy hypothesis - that is, assumes it to be true, as in previous research — by constrain-

47. If we include cases where trade falls below $\$ 100,000$, the number of Article XXXV invocations increases by about 400 , but the results are qualitatively similar.

48. To save space, we do not report the full regression results for these equations.

49. We also include currency unions but do not attempt to incorporate them within this hierarchy. 
TABLE 6. Trade agreements-hierarchical or additive?

\begin{tabular}{|c|c|c|}
\hline & $\begin{array}{l}\text { Hierarchy } \\
\text { imposed }\end{array}$ & $\begin{array}{c}\text { Hierarchy } \\
\text { tested }\end{array}$ \\
\hline Colonial orbit & $\begin{array}{l}1.10 \\
(.08)\end{array}$ & $\begin{array}{l}.80 \\
(.10)\end{array}$ \\
\hline \multicolumn{3}{|l|}{ Reciprocal PTA } \\
\hline No colonial orbit & $\begin{array}{c}.65 \\
(.04)\end{array}$ & $\begin{array}{c}.30 \\
(.07)\end{array}$ \\
\hline With colonial orbit & - & $\begin{array}{l}.23 \\
(.09)\end{array}$ \\
\hline \multicolumn{3}{|l|}{ Both in the GATT/WTO } \\
\hline Neither colonial orbit nor reciprocal PTA & $\begin{array}{l}.30 \\
(.03)\end{array}$ & $\begin{array}{l}.36 \\
(.03)\end{array}$ \\
\hline With colonial orbit and/or reciprocal PTA & - & $\begin{array}{l}.44 \\
(.07)\end{array}$ \\
\hline \multicolumn{3}{|l|}{ One in the GATT/WTO } \\
\hline Neither colonial orbit nor reciprocal PTA & $\begin{array}{l}.19 \\
(.03)\end{array}$ & $\begin{array}{l}.22 \\
(.03)\end{array}$ \\
\hline With colonial orbit and/or reciprocal PTA & - & $\begin{array}{l}.15 \\
(.07)\end{array}$ \\
\hline \multicolumn{3}{|l|}{ Nonreciprocal (PTA or GSP) } \\
\hline No colonial orbit, GATT/WTO, or reciprocal PTA & $\begin{array}{l}.39 \\
(.11)\end{array}$ & $\begin{array}{l}.34 \\
(.11)\end{array}$ \\
\hline With colonial orbit, GATT/WTO, or reciprocal PTA & - & $\begin{array}{r}-.11 \\
(.02)\end{array}$ \\
\hline Currency union & $\begin{array}{l}.51 \\
(.08)\end{array}$ & $\begin{array}{l}.50 \\
(.09)\end{array}$ \\
\hline Log product real GDP & $\begin{array}{l}.67 \\
(.01)\end{array}$ & $\begin{array}{l}.66 \\
(.01)\end{array}$ \\
\hline Standard error of the regression & .94 & .94 \\
\hline$R^{2}$ & .84 & .84 \\
\hline$N$ & 381,656 & 381,656 \\
\hline
\end{tabular}

Notes: Estimates from ordinary least squares (OLS) regression. For both models, the unit of observation is the directed dyad and the dependent variable is the natural log of imports (measured in 1967 U.S. dollars). The data cover fifty-nine years and 17,359 directed dyads. Both models include fixed effects for directed dyads and years. Robust standard errors, clustered by directed dyad, appear in parentheses.

ing the effect of PTAs to be 0 for dyads within the same colonial orbit, and by constraining the effects of the GATT/WTO and nonreciprocal agreements to be 0 for dyads within the same colonial orbit or PTA. At first glance, the pattern of coefficients seems consistent with a hierarchy. Colonial relations have a larger effect than PTAs, which in turn seem more consequential than either the GATT/WTO or nonreciprocal agreements.

But this finding dissolves when we test, rather than impose, the hierarchy hypothesis. The second equation allows the effects of PTAs, the GATT/WTO, and nonreciprocal agreements to vary according to whether a higher-order arrangement exists. The effects of trade agreements appear not to depend on the presence or absence of higher-order institutions. PTAs exert positive effects of similar magni- 
TABLE 7. Increase in trade with and without higher-order agreements

\begin{tabular}{lccccr}
\hline & $\begin{array}{l}\text { Colonial } \\
\text { orbit }\end{array}$ & $\begin{array}{l}\text { Reciprocal } \\
\text { PTA }\end{array}$ & $\begin{array}{l}\text { Both in } \\
\text { GATT/WTO }\end{array}$ & $\begin{array}{l}\text { One in } \\
\text { GATT/WTO }\end{array}$ & $\begin{array}{l}\text { Nonreciprocal } \\
\text { agreement }\end{array}$ \\
\hline $\begin{array}{l}\text { No higher-order agreement } \\
\text { Higher-order agreement }\end{array}$ & $123 \%$ & $35 \%$ & $43 \%$ & $25 \%$ & $41 \%$ \\
& & $26 \%$ & $55 \%$ & $17 \%$ & $-10 \%$ \\
\hline
\end{tabular}

Notes: Entries are the estimated percentage increase in trade when both countries have the relationship described by the column label, relative to when no such relationship exists. Each effect is calculated as an arc elasticity, $e^{\hat{\beta}}-1$, where $\hat{\beta}$ is the appropriate parameter estimate from the full model (hierarchy tested) in Table 6.

tude, whether or not the parties have colonial relations. Similarly, the GATT/ WTO stimulates trade at least as much when countries already have colonial relations or a PTA, as when they have no higher-ranked agreements. This is contrary to the hierarchy hypothesis, which implies that the GATT/WTO should have exerted no force in dyads with either a PTA or colonial relations. The only evidence of a possible hierarchy concerns nonreciprocal agreements, which are more consequential when they exist in isolation. Overall, the hierarchy restrictions imposed in the first equation are easily rejected. ${ }^{50}$ Table 7 reports the percentage effects on trade implied by our test of the hierarchy hypothesis.

Given that the effects of one agreement do not appear to be influenced much by the presence of others, we now consider how each agreement has evolved over time. We analyze temporal effects with cubic splines, which permit the impact of each agreement to vary over the years in a flexible but smooth way. The results are illustrated in Figure 1, with estimates for selected years shown in Table 8.

The figure and the table imply that the GATT/WTO effect has not remained constant over time. Instead, we find that participation stimulated trade to the greatest degree in the early years: more than 90 percent in 1948. The effects then fell gradually, and by the turn of the century were only about 11 percent for the average participating dyad. These effects are calculated by comparing dyads where both countries participate in the GATT/WTO to dyads where neither participates. Of course, by 2000 few countries remained outside the organization, so the relatively small per-dyad effect applies to a much larger set of countries.

Figure 1 also shows that the effect of colonialism has waned. In contrast to the GATT/WTO, where the number of participants increased, colonial relationships had all but vanished by the beginning of the twenty-first century. The effect of being in the same colonial orbit was enormous in 1950 (147 percent), but its impact declined to 32 percent in 1980 , by which time nearly all colonies had achieved independence. The effect of PTAs has trended in the opposite direction, and today these preferential agreements are an important determinant of 


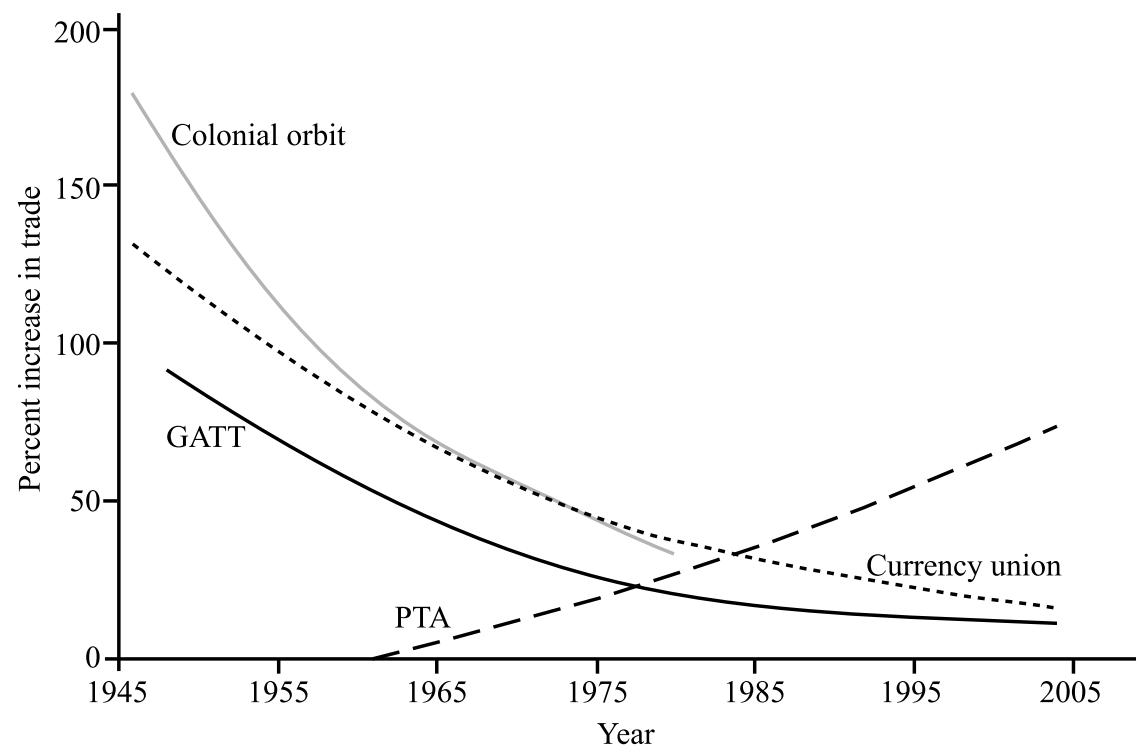

Note: The figure shows the estimated increase in trade, in percentage points, from participation in different types of agreements. Estimates were obtained using natural cubic splines in time, as discussed in the text and summarized in Table 8.

FIGURE 1. The effects of international agreements over time

TABLE 8. Effects of international agreements over time

\begin{tabular}{lccccr}
\hline Year & $\begin{array}{c}\text { Both in } \\
\text { GATT/WTO }\end{array}$ & $\begin{array}{c}\text { One in } \\
\text { GATT/WTO }\end{array}$ & $\begin{array}{c}\text { Reciprocal } \\
\text { PTA }\end{array}$ & $\begin{array}{c}\text { Colonial } \\
\text { orbit }\end{array}$ & $\begin{array}{c}\text { Currency } \\
\text { union }\end{array}$ \\
\hline 1950 & 85 & 22 & & 147 & 115 \\
1960 & 55 & 19 & -1 & 86 & 81 \\
1970 & 33 & 16 & 11 & 55 & 54 \\
1980 & 20 & 11 & 26 & 32 & 37 \\
1990 & 14 & 7 & 44 & & 26 \\
2000 & 11 & 2 & 64 & & 18 \\
\hline
\end{tabular}

Note: Entries are the estimated percentage increase in trade when both countries have the relationship described by the column label, relative to when no such relationship exists. All estimates in the table are based on a pooled ordinary least squares (OLS) regression in which the unit of observation was the directed dyad and the dependent variable was the natural $\log$ of imports (measured in 1967 U.S. dollars). The regression involved 381,656 observations, which covered fifty-nine years and 17,359 directed dyads. The effect of each international agreement in the table was modeled as a natural cubic spline function with three knots. For "Both in GATT" and "One in GATT," knots were placed at 1953, 1976, and 1999; for "Reciprocal PTA," knots were placed at 1963, 1981, and 1999; for "Colonial orbit," knots were placed at 1951, 1960, and 1970; and for "Currency union," knots were placed at 1951, 1975, and 1999. Figures in the table were obtained by evaluating the estimated spline functions at ten-year intervals. The regression included fixed effects for directed dyads and years, as well as controls for nonreciprocal PTAs, GSP, and the log product of real GDP. The standard error of the regression was .94 , and the $R^{2}$ was .84 . 
trade. Importantly, the growth of PTAs has not eliminated the effects of the GATT/WTO.

The estimates for nonreciprocal agreements are difficult to interpret, and we can say little about these institutions that is definitive. In the absence of the GATT/ WTO, a colonial orbit, or a reciprocal PTA, one-sided preferences increased trade by 41 percent (see Table 7). But, in the presence of these other institutions, countries appear to be worse off if they receive preferences. This finding is implausible but resistant to manipulation. ${ }^{51}$ We leave this as a mystery yet to be solved.

Finally, we estimated the effect of belonging to currency unions, which have been strong predictors of trade in previous models. ${ }^{52}$ As with colonialism and the GATT/WTO, the impact of currency unions has faded over time. In 1950, for example, members of a currency union traded 115 percent more than those outside a currency union. By 2000, the boost in trade was only about 18 percent. In part, the deepening of capital markets and worldwide currency convertibility may have made currency unions less critical to trade.

\section{Conclusions}

In this article, we have shown how the GATT/WTO influenced patterns of international commerce. Trade among those with standing in the GATT/WTO was considerably higher than what one would predict, based purely on proximity, national income, and other nonpolitical variables. The analysis not only confirms that the institution stimulated trade but also identifies to whom and during what time periods the agreement had its greatest impact. The benefits of the GATT/WTO extended to all members, including developing nations, many of which today argue that they have gained little from international rules.

Our conclusions about the efficacy of international cooperation were based on a new approach to participation in international organizations. To advance our understanding of trade agreements, we introduced the concept of institutional standing. Archival evidence confirms that the GATT/WTO created rights and obligations not only for formal members but also for a wide range of nonmember participants, including colonies and newly independent states. Previous research, which focused exclusively on formal members, erroneously concluded that the GATT/ WTO had no effect. By broadening the analysis to include all parties with standing, we demonstrated that the institution transformed postwar trade.

The GATT/WTO never existed in isolation, however; nations belonged to many other trade agreements. We introduced the concept of institutional embeddedness

51. For example, we separated the effects of preferences on the importing and exporting country, assuming that the exporting country would derive the larger benefit. The result was the opposite, with the even more counterintuitive finding that the country that granted the preference received a trade benefit, whereas the importing nation did not.

52. See Rose 2002 and 2004. 
to describe and analyze the effect of multiple memberships. We found that postwar trade agreements typically have not undercut one other. To the contrary, they have created interrelated and often complementary rule systems that support international trade. Each is part of a larger network of agreements that have helped the world move from relative closure after World War II to unprecedented levels of trade today.

The empirical analysis in this article focuses on trade, but our work suggests other avenues for research. We have found, for example, that standing in the GATT/ WTO is not coterminous with membership. Future research should measure the extent of nonmember participation in financial agreements, environmental accords, military alliances, and other fields beyond trade, and examine the effects of nonmember participation on behavior. Likewise, scholars should document the degree to which formal members opt out of contractual obligations and see how such reservations affect patterns of international cooperation.

In the process, it is important not to overlook the role of dependent territories and semi-sovereign states. Theorists of international relations tend to model the strategic interaction between sovereign countries, and empirical researchers typically drop colonies and territories from their data sets. This approach, though reasonable for many inquires, misses some of the most interesting patterns in international relations. By incorporating nonsovereign territories into the analysis, we obtained a more accurate understanding of where and how the GATT/ WTO contributed to international trade after World War II.

The concept of embeddedness also has wide-reaching implications for other areas of international relations. In an increasingly complex world, we observe overlapping agreements in a number of areas, not just in trade. Countries belong to NATO, but they also forge special security agreements with narrower groups and individual countries. Nations enter into multilateral agreements on the environment, but at the same time they develop unique agreements with neighboring states that would otherwise receive the brunt of each other's pollution. Governments sign letters of intent with the IMF, even while devising special arrangements with selected international banks and foreign state creditors. In a world where countries enter multiple agreements, we must examine agreements in context, rather than studying each agreement in isolation. The findings in this article show that such an approach can pay valuable dividends for understanding international relations.

\section{Appendix: Countries in the Sample}

$\begin{array}{llll}\text { Afghanistan } & \text { El Salvador } & \text { Lebanon } & \text { Senegal } \\ \text { Albania } & \text { Eritrea } & \text { Lesotho } & \text { Serbia and Montenegro } \\ \text { Algeria } & \text { Estonia } & \text { Liberia } & \text { Sierra Leone } \\ \text { Angola } & \text { Ethiopia } & \text { Libya } & \text { Singapore } \\ \text { Argentina } & \text { Finland } & \text { Lithuania } & \text { Slovakia } \\ \text { Armenia } & \text { France } & \text { Macedonia } & \text { Slovenia } \\ \text { Australia } & \text { Gabon } & \text { Madagascar } & \text { Somalia }\end{array}$




$\begin{array}{llll}\text { Austria } & \text { Gambia } & \text { Malawi } & \text { South Africa } \\ \text { Azerbaijan } & \text { Georgia } & \text { Malaysia } & \text { Spain } \\ \text { Bangladesh } & \text { Germany } & \text { Mali } & \text { Sri Lanka } \\ \text { Belarus } & \text { Germany East } & \text { Mauritania } & \text { Sudan } \\ \text { Belgium } & \text { Germany West } & \text { Mauritius } & \text { Swaziland } \\ \text { Benin } & \text { Ghana } & \text { Mexico } & \text { Sweden } \\ \text { Bhutan } & \text { Greece } & \text { Moldova } & \text { Switzerland } \\ \text { Bolivia } & \text { Guatemala } & \text { Mongolia } & \text { Syria } \\ \text { Bosnia } & \text { Guinea } & \text { Morocco } & \text { Taiwan } \\ \text { Botswana } & \text { Guinea-Bissau } & \text { Mozambique } & \text { Tajikistan } \\ \text { Brazil } & \text { Haiti } & \text { Myanmar } & \text { Tanzania } \\ \text { Bulgaria } & \text { Honduras } & \text { Namibia } & \text { Thailand } \\ \text { Burkina Faso } & \text { Hong Kong } & \text { Nepal } & \text { Togo } \\ \text { Burundi } & \text { Hungary } & \text { Netherlands } & \text { Trinidad and Tobago } \\ \text { Cambodia } & \text { India } & \text { New Zealand } & \text { Tunisia } \\ \text { Cameroon } & \text { Indonesia } & \text { Nicaragua } & \text { Turkey } \\ \text { Canada } & \text { Iran } & \text { Niger } & \text { Turkmenistan } \\ \text { Central African Rep. } & \text { Iraq } & \text { Nigeria } & \text { UK } \\ \text { Chad } & \text { Ireland } & \text { Norway } & \text { USA } \\ \text { Chile } & \text { Israel } & \text { Oman } & \text { USSR } \\ \text { China } & \text { Italy } & \text { Pakistan } & \text { Uganda } \\ \text { Colombia } & \text { Ivory Coast } & \text { Panama } & \text { Ukraine } \\ \text { Congo (Brazzaville) } & \text { Jamaica } & \text { Papua New Guinea } & \text { United Arab Emirates } \\ \text { Congo (Kinshasa) } & \text { Japan } & \text { Paraguay } & \text { Uruguay } \\ \text { Costa Rica } & \text { Jordan } & \text { Peru } & \text { Uzbekistan } \\ \text { Croatia } & \text { Kazakhstan } & \text { Philippines } & \text { Venezuela } \\ \text { Cuba } & \text { Kenya } & \text { Poland } & \text { Vietnam } \\ \text { Czech Republic } & \text { Korea North } & \text { Portugal } & \text { West Bank } \\ \text { Czechoslovakia } & \text { Korea South } & \text { Puerto Rico } & \text { Yemen North } \\ \text { Denmark } & \text { Kuwait } & \text { Romania } & \text { Yemen South } \\ \text { Dominican Republic } & \text { Kyrgyzstan } & \text { Russia } & \text { Yemen } \\ \text { Ecuador } & \text { Laos } & \text { Rwanda } & \text { Yugoslavia } \\ \text { Egypt } & \text { Latvia } & \text { Saudi Arabia } & \text { Zambia } \\ & & & \text { Zimbabwe } \\ & & \end{array}$

\section{References}

Anderson, James, and Eric van Wincoop. 2003. Gravity with Gravitas: A Solution to the Border Puzzle. American Economic Review 93 (1):170-92.

Bagwell, Kyle, and Robert W. Staiger. 1999. An Economic Theory of GATT. American Economic Review 89 (1):214-48.

- 2002a. Economic Theory and the Interpretation of GATT/WTO. American Economist 46 (2):3-19.

. 2002b. The Economics of the World Trading System. Cambridge, Mass.: MIT Press.

Baier, Scott L., and Jeffrey H. Bergstrand. Forthcoming. Do Free Trade Agreements Actually Increase Members' International Trade? Journal of International Economics. Available at 〈http://people. clemson.edu/ sbaier/FTA2\%20v02\%20Oct\%202004.pdf〉. Accessed 12 July 2006.

Bailey, Michael A., Judith Goldstein, and Barry R. Weingast. 1997. The Institutional Roots of American Trade Policy: Politics, Coalitions, and International Trade. World Politics 49 (3):309-38. 
Barton, John, Judith Goldstein, Tim Josling, and Richard Steinberg. 2006. The Evolution of the Trade Regime: Politics, Law and Economics of the GATT and WTO. Princeton, N.J.: Princeton University Press.

Bhagwati, Jagdish. 1991. The World Trading System at Risk. Princeton, N.J.: Princeton University Press. 1992. Regionalism versus Multilateralism. The World Economy 15 (5):535-55.

Bhagwati, Jagdish, and Arvind Panagariya. 1996. Preferential Trading Areas and Multilateralism: Strangers, Friends or Foes? In The Economics of Preferential Trade Agreements, edited by Jagdish Bhagwati and Arvind Panagariya, 1-78. Washington, D.C.: AEI Press.

Chamberlain, Gary, and Edward E. Leamer. 1976. A Bayesian Interpretation of Pretesting. Journal of the Royal Statistical Society, Series B 38 (1):85-94.

Conference Board/Groningen Growth and Development Centre. 2003. Total Economy Database. Groningen, Netherlands: University of Groningen. Available at 〈http://www.ggdc.net $\rangle$. Accessed 12 July 2006.

Corden, W. M. 1976. Customs Union Theory and the Nonuniformity of Tariffs. Journal of International Economics 6 (1):99-106.

Feenstra, Robert C. 2004. Advanced International Trade: Theory and Evidence. Princeton, N.J.: Princeton University Press.

Frankel, Jeffrey A. 1997. Regional Trading Blocs in the World Economic System. Washington, D.C.: Institute for International Economics.

Frieden, Jeffry, and Lisa L. Martin. 2002. International Political Economy: Global and Domestic Interactions. In Political Science: The State of the Discipline, edited by Ira Katznelson and Helen V. Milner, 118-46. New York: Norton.

General Agreement on Tariffs and Trade (GATT). 1961. The Activities of GATT 1960/61. Geneva: GATT.

Basic Instruments and Selected Documents (BISD). Various years. Geneva: GATT.

Gilligan, Michael J. 1997. Lobbying as a Private Good with Intra-Industry Trade. International Studies Quarterly 41 (3):455-74.

Gowa, Joanne, and Soo Yeon Kim. 2005. An Exclusive Country Club: The Effects of GATT on Trade, 1950-92. World Politics 57 (4):453-78.

Heston, Alan, Robert Summers, and Bettina Aten. 2002. Penn World Table Version 6.1. Philadelphia: Center for International Comparisons at the University of Pennsylvania.

International Monetary Fund (IMF). 2005a. Direction of Trade Statistics. Washington, D.C.: IMF.

—. 2005b. International Financial Statistics. Washington, D.C.: IMF.

Irwin, Douglas A. 1995. The GATT in Historical Perspective. American Economic Review 85 (2):323-28.

—. 2002. Free Trade Under Fire. Princeton, N.J.: Princeton University Press.

Jackson, John Howard. 1997. The World Trading System: Law and Policy of International Economic Relations. Cambridge, Mass.: MIT Press.

Kahler, Miles. 1995. International Institutions and the Political Economy of Integration. Washington, D.C.: Brookings Institution.

Keohane, Robert O. 1984. After Hegemony: Cooperation and Discord in the World Political Economy. Princeton, N.J.: Princeton University Press.

Krueger, Anne. 1997. Free Trade Agreements versus Customs Unions. Journal of Development Economics 54 (1):169-87.

Lawrence, Robert Z. 1999. Regionalism, Multilateralism and Deeper Integration: Changing Paradigms for Developing Countries. In Trade Rules in the Making: Challenges in Regional and Multilateral Negotiations, edited by Miguel Rodrígues Mendoza, Patrick Low, and Barbara Kotschwar, 23-46. Washington, D.C.: Brookings Institution.

Maddison, Angus. 1995. Monitoring the World Economy, 1820-1992. Paris: Organisation for Economic Cooperation and Development (OECD) Development Centre.

2001. The World Economy: A Millennial Perspective. Paris: OECD Development Centre.

. 2003. World Population, GDP and Per Capita GDP, 1-2000 AD. Available at 〈http://www. ggdc.net/maddison/content.shtml $\rangle$. Accessed 12 July 2006.

Maggi, Giovanni, and Andrés Rodríguez-Clare. 1998. The Value of Trade Agreements in the Presence of Political Pressures. Journal of Political Economy 106 (3):574-601. 
Mansfield, Edward D., and Helen V. Milner. 1999. The New Wave of Regionalism. International Organization 53 (3):589-627.

Mansfield, Edward D., and Eric Reinhardt. 2003. Multilateral Determinants of Regionalism: The Effects of GATT/WTO on the Formation of Preferential Trading Arrangements. International Organization 57 (4):829-62.

Ozden, Caglar, and Eric Reinhardt. 2005. The Perversity of Preference: GSP and Developing Country Trade Policies, 1976-2000. Journal of Development Economics 78 (1):1-21.

Rose, Andrew K. 2002. Honey, The Currency Union Effect on Trade Hasn't Blown Up. World Economy 25 (4):475-79.

- 2004. Do We Really Know That the WTO Increases Trade? American Economic Review 94 (1):98-114.

Rosendorff, B. Peter, and Helen V. Milner. 2001. The Optimal Design of International Trade Institutions: Uncertainty and Escape. International Organization 55 (4):829-57.

Ruggie, John Gerard. 1993. Multilateralism Matters: The Theory and Praxis of an Institutional Form. New York: Columbia University Press.

Shanks, Cheryl, Harold K. Jacobson, and Jeffrey H. Kaplan. 1996. Inertia and Change in the Constellation of International Governmental Organizations, 1981-1992. International Organization 50 (4):593-627.

Staiger, Robert W., and Guido Tabellini. 1987. Discretionary Trade Policy and Excessive Protection. American Economic Review 77 (5):823-37.

— 1999. Do GATT Rules Help Governments Make Domestic Commitments? Economics and Politics 11 (2):109-44.

Stone, Charles J. 1994. The Use of Polynomial Splines and Their Tensor Products in Multivariate Function Estimation (with Discussion). The Annals of Statistics 22 (1):118-84.

Subramanian, Arvind, and Shang-Jin Wei. Forthcoming. The WTO Promotes Trade, Strongly but Unevenly. Journal of International Economics.

Tomz, Michael, Judith Goldstein, and Douglas Rivers. 2005. Membership Has Its Privileges: The Impact of the GATT on International Trade. Unpublished manuscript, Department of Political Science, Stanford University, California.

United States. Geographic Names Division. 1988. Gazetteer of Conventional Names. 3d ed. Washington, D.C.: Defense Mapping Agency.

Viner, Jacob. 1950. The Customs Union Issue. New York: Carnegie Endowment for International Peace. World Bank. 2005. World Development Indicators. Washington, D.C.: World Bank. 